\title{
Transformation of traditional shifting cultivation into permanent cropping systems: a case study in Sarayaku, Ecuador
}

\author{
$\underline{\text { Hannes Schritt }}^{1}$, Christine Beusch $^{1}, \underline{\text { Pedro Ríos Guavasamín }}^{2,3,4}$ and Martin Kaupenjohann $^{1}$
}

\begin{abstract}
Slash-and-burn shifting cultivation is common in indigenous societies in the Amazon basin. The large land use of this farming practice is of increasing concern because most indigenous communities are faced with population growth and territory losses. Our study aims to evaluate the feasibility of transforming shifting cultivation into a permanent cropping system by application of Terra Preta practice. For this purpose, an overview of the nutrient cycles of the agroecosystem of an indigenous family in Sarayaku, located in the eastern lowlands of the Ecuadorian Amazon, is provided. Household nutrient input and output data were collected and complemented with information from literature. The balances of nitrogen, phosphorus, and potassium were calculated in five different scenarios: (I) recycling of household waste; (II) recycling of household waste and urine; (III) recycling of household waste, urine, and feces. Whereas the first three scenarios include an external wood source, IV and V additionally integrate a tree plantation. In scenario IV the tree plantation is fertilized only with feces, while in V also with household waste. Even after consideration of nutrient losses, scenarios II to $\mathrm{V}$ show potential to accumulate nutrients at the farmland. These results indicate the feasibility of closing nutrient cycles with the purpose to generate permanent farmland by combining knowledge of Terra Preta practice and the way of life of indigenous communities. In a described step by step manner this new agricultural system could be implemented and improve greatly resilience and sustainability of land use in the Amazon.
\end{abstract}

Key Words: ecological sanitation; Ecuadorian Amazonia; resilience; sustainable agriculture; Terra Preta practice

\section{INTRODUCTION}

While the global population is rising, arable land is running short. Especially in the tropics, the increasing demand for land leads to deforestation and degradation of the soils (Steiner et al. 2007). With 300 to 500 million practitioners, shifting cultivation, combined with slash-and-burn techniques, is still the most common form of land use worldwide (Giardina et al. 2000, Steiner et al. 2007), as it is in our study area.

Intact tropical rain forests are characterized by closed nutrient cycles through tight links between litter fall and immediate rootuptake of the nutrients from rapidly decomposed organic material (Vitousek and Sanford 1986). In slash-and-burn cultivation, the nutrients of the combusted biomass become easily available for crops, but the nutrient cycle is interrupted (Giardina et al. 2000). The predominant highly weathered soils of the lowland humid tropics have a small nutrient retention capacity and thus loose nutrients rapidly. This leads to short periods of only up to three years of productive agriculture after burning (Tiessen et al. 1994). Replenishment of nutrients happens mostly by deposition and nitrogen $(\mathrm{N})$ fixation through leguminous plants. Active fertilization or recycling of nutrients are unusual. To recover the nutrient status, a fallow period of up to 20 years is needed (Kleinman et al. 1996). As a result of population growth, which marks a current trend in many indigenous communities inhabiting tropical forests, fallow periods are often reduced, leading to severe soil degradation, resulting in low food production and hunger (Steiner et al. 2007). Therefore, efficient alternative agricultural production systems must be found in order to achieve food security.

There is a growing scientific interest in terra preta (TP; Portuguese for "black soil"). Terra preta refers to a soil created by preColumbian settlements in the Amazonian rain forest (Glaser
2006). These anthropogenic soils contain three times more organic carbon $(\mathrm{C})$ in average, are richer in mineral nutrients, especially phosphorus $(\mathrm{P})$, and are characterized by a larger nutrient retention capacity of TP than surrounding natural soils (Novotny et al. 2009, Glaser and Birk 2012). The crop production potential is usually much larger than in adjacent soils (Lehmann et al. 2003a). It was mostly discovered on nonfloodable land near pre-Columbian settlements (Denevan 1996, Glaser and Birk 2012). Comprehensive studies on the reason and origin of the high content of nutrients in TP have been conducted by Glaser (2006) and Glaser and Birk (2012). Human excreta and bone material, mostly from mammals and fishes, have been found in TP and could explain the high contents especially of $P$ and calcium (Ca; Glaser and Birk 2012). Also, ash and charcoal (referred to as biochar) have been found in the TP. At present, its ancient production process is not completely unraveled, but it is clear that nutrients were recycled leading to an enhanced agricultural productivity that facilitated permanent cropping (Glaser and Birk 2012). Recent studies emphasize terra preta practices (TPP) as an alternative to slash-and-burn techniques (e.g., Glaser and Birk 2012, De Gisi et al. 2014).

A worldwide common method to recycle nutrients is to compost organic residue. It is used to treat household residue that can be reused as soil conditioner. In this process, organic material is decomposed by bacteria, fungi, and insects into humus after a period of months. At the simplest level, it requires only a heap of wet organic matter. The decomposition process can be supported by shredding the organic material, adding water, and ensuring proper aeration (Haug 2015).

Biochar, which has been found in TP, could play a major role to improve nutrient retention in the highly weathered soils of the Amazon (Batista et al. 2018). It creates a stable stock of organic

\footnotetext{
${ }^{1}$ Institute of Ecology, Department of Soil Science, Technische Universität Berlin, Germany, ${ }^{2}$ Laboratorio de Ecología Tropical Natural y Aplicada, Facultad de Ciencias de la Vida, Universidad Estatal Amazónica, Puyo, Pastaza, Ecuador, ${ }^{3}$ CIPCA, Napo, Ecuador, ${ }^{4}$ Faculty of Forestry, University of Toronto, Ontario, Canada
} 
matter in the soil, is considered to be the main factor for the persistence of TP, and might have been added purposely to ancient compost procedures (Glaser and Birk 2012). Many studies emphasize the positive effect of biochar on soil fertility and crop yield (Lehmann et al. 2003b, Steiner et al. 2007, Verheijen et al. 2010, Agegnehu et al. 2015). Nutrient retention by biochar has been reported, especially for nitrate and phosphate (Lehmann et al. 2003b, Dempster et al. 2012).

Another amendment to improve nutrient retention and nutrient status might also be clayey river sediment, while its ancient role by creation of TP remains unclear (Herrera et al. 1992, Guyot et al. 2007). Although its historical role remains unclear, mixing clayey river sediment with soil can also improve nutrient retention (Guyot et al. 2007, Beusch et al. 2019) and nutrient status (Herrera et al. 1992). Furthermore, addition of clay to compost leads to enhanced nutrient retention (Nguyen and Marschner 2013).

Recent studies working on TPP combine cycling of nutrients with new sanitation systems and biochar (De Gisi et al. 2014, Krause et al.2015). Part of these scenarios include the separation of urine, feces, and greywater for further processing. According to the WHO (2006), untreated or briefly stored urine is safe to be used as a fertilizer. In contrast, feces contain various pathogens (bacteria, viruses, and worm eggs) and require appropriate processing (WHO 2006).

To our knowledge there is no research on the present diet and nutrient fluxes involved in the indigenous way of life and the opportunities achieved by TPP for indigenous agriculture. Thus, the overall aim of this study is to assess the feasibility of achieving permanent cropping by the closing of nutrient cycles and application of TPP in the form of a holistic study. We hypothesize that the combination of the traditional, indigenous way of life with TPP will improve nutrient status of the soils leading to extended cropping periods up to permanent cropping systems.

\section{METHODS}

\section{Study site}

The methodical approach of this study combined a field survey, laboratory analyses, and a literature review. Nutrient balances of $\mathrm{N}, \mathrm{P}$, and potassium $(\mathrm{K})$ were calculated in five different scenarios, based on nutrient data collected from one household in the indigenous community of Sarayaku, Ecuador.

The study was conducted in Sarayaku (400 m a. s. $1 ., 1^{\circ} 44^{\prime} \mathrm{S}, 77^{\circ}$ $29^{\prime} \mathrm{W}$ ), an indigenous village in the eastern lowlands of Ecuador (Fig. 1). The closest city, Puyo, is about $65 \mathrm{~km}$ away. As part of the Pastaza province, Sarayaku is located east of the Andes in the Amazon basin on the banks of the river Bobonaza. The settlements of Sarayaku are situated in the humid rain forest. Annual rainfall varies between 3000 and $3500 \mathrm{~mm}$ and the mean temperature is $23^{\circ} \mathrm{C}$ (Sirén 2004). Geologically, the area is characterized by fluvial deposits that were uplifted by Pliocene Andean tectonism (Räsänen et al. 1990), followed by heavy erosion resulting in a rugged landscape with ridges and small valleys (Sirén 2014). The water level of the river varies extensively. Periodically it carries new sediments and leaves patches of clayey and sandy sediments at the river banks and flood plains.
Fig. 1. Location of Sarayaku in the eastern lowlands of Ecuador (adapted from Zapata-Ríos 2001).

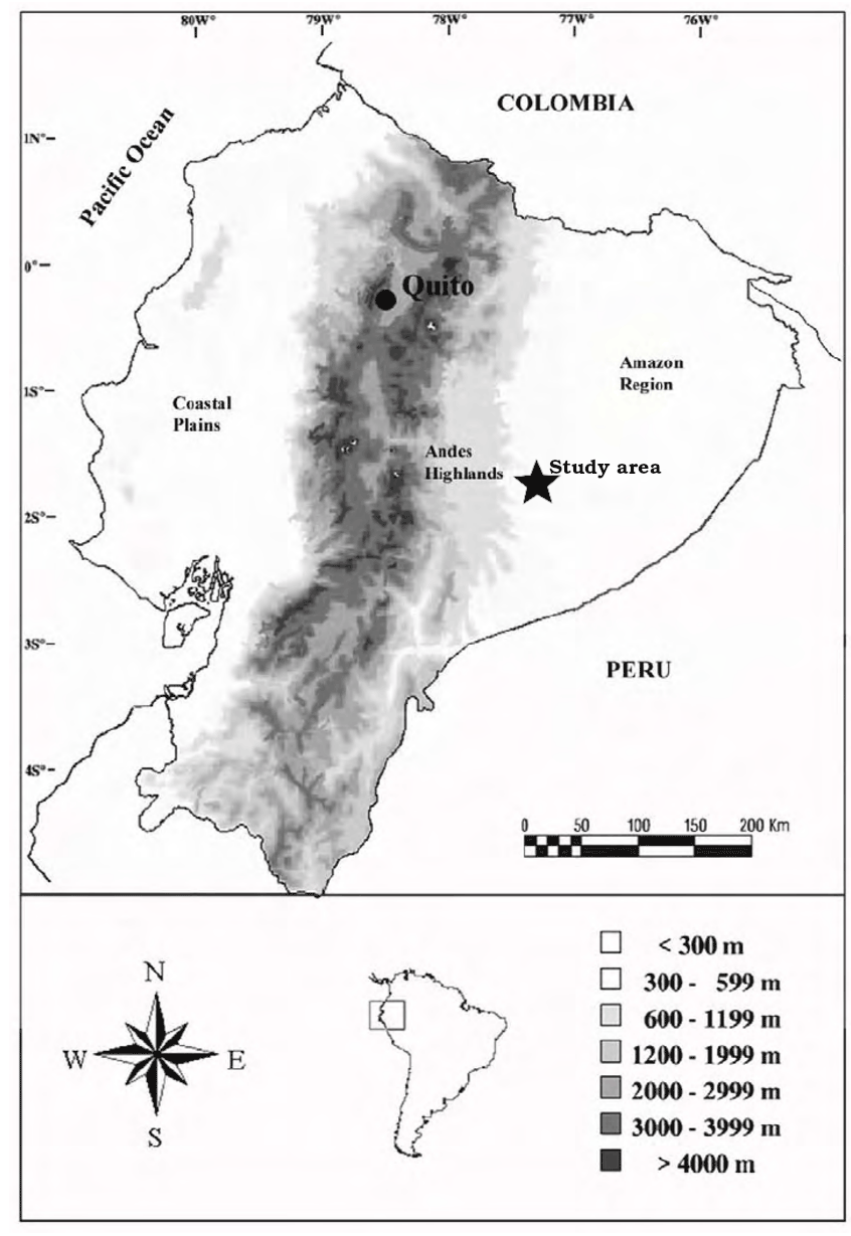

Sarayaku has about 1000 inhabitants in five different hamlets. The population grew annually by about $1.6 \%$ in the last decades (Sirén 2007). The community currently claims an area of approximately $1400 \mathrm{~km}^{2}$ as its territory (Sirén 2014). For decades, Sarayaku has been known for its resistance against oil extraction. The resources driven invasion of companies and farmers has led to ongoing, and to some extent violent, territory conflicts (see also Figueroa 2006). Sarayaku is only loosely connected to the market economy. The subsistence economy is based on shifting cultivation, fishing, and hunting. The community is organized democratically with elected leaders of different sectors, e.g., a leader of women and a leader of the community. The households are mostly organized in family units. There are different houses for different purposes, e.g., gathering, cooking, sleeping, and a toilet. The families cook with wood collected downstream of the river. Because people in Sarayaku process wood quite frequently, e.g., while slashing new farmland, creating new buildings, or collecting wood, sawdust is a frequent byproduct of the Sarayaku lifestyle. Also, rotten wood is usually available in the forest with a structure similar to sawdust. 
Both men and women work the farmland. After slashing, drying, and burning the above-ground biomass, farmers plant directly between the stumps. The burning residue leaves patches of ash, coal, and litter. In general, cultivation works without any further soil treatment or fertilizer addition. The main agricultural tools are machete and ax. Cultivation between two and three years is a common practice, depending on the soil fertility. To ensure soil recovery, cultivated land is usually followed by a fallow period of 20 years. Usually each household has three fields, with an average of 0.2 ha (Sirén and Machoa 2008): one in seedbed preparing or already in seeding status, one in growing status, and one in harvesting status. The heterogeneous landscape leads to farmlands on different expositions and soil types. As a consequence, it is common to have at least a second farm uphill (as flood insurance) if the farmers cultivate in the flood plain. The sandy sediments are especially used for cultivation in the flood plains. Furthermore, the cultivated crop species vary depending on soil and exposition. The most important crops are cassava (Manihot esculenta), plantain (Musa sp.), and maize (Zea mays). Only roots and fruits with peel are harvested, while leaves and all other plant residue is left at the farmland. Within a radius of up to five kilometers to the villages, almost all arable land is in use (Sirén and Machoa 2008). Thus, population growth demands longer distances to farmlands, a shorter fallow period, or other sources of cash income. The annual increase of cultivated area is still modest at $0.4 \%$ because of new income through governmental salaries, tourism, migratory labor, and trading that enables village inhabitants to buy their food resources elsewhere (Sirén 2007). Even so, increasing poultry, cattle, and fish ponds constitute a minor complementary food source. Population growth has led to a serious decrease in wildlife in the territory of Sarayaku (Sirén 2012). According to the local people, fish resources are declining as well, especially regarding migratory fishes (Sirén and Machoa 2008). Hunting and fishing might thus become an insecure food source.

\section{Research strategy}

One family was accompanied over 10 days at the end of October 2014. With respect to local culture, the study was based on only one participating family, because being inquisitive about food procurement and consumption is considered impolite in Sarayaku (see also Sirén and Machoa 2008). Following discussions with the family member Antonia Aranda, the family had standard habits concerning their lifestyle as subsistence farmers, the size of thier cultivated farmland, their family structure, and their general lifestyle compared to other families. The family relies only to a small extent on external food supplementation (cf. Sirén 2004).

The weights of all inputs and outputs to the household were determined every day for six days from 24 to 29 October 2014. Samples were taken for the analyzing procedure. Food supply bought from the local store could not be quantified, but interviews conducted with family member Antonio Aranda gave an approximation of this input. In order to calculate the scenarios, the wood type that is usually used for cooking was also collected.

Soil samples were taken from farmland close to the village to a depth of $0-20 \mathrm{~cm}$ and $20-40 \mathrm{~cm}$ and from the clayey and sandy patches of the river sediments. For each area, five samples were collected and mixed internally. Bulk density of the soil was obtained by sampling rings $\left(113 \mathrm{~cm}^{3}\right)$; two samples on five plots were taken at depths of $8-12$ and $28-32 \mathrm{~cm}$. Soil texture was analyzed in the field according to AG-Boden (2006). All samples were first air-dried and then oven-dried at $40^{\circ} \mathrm{C}$ for at least 24 hours at Universidad Estatal Amazónica. After transport, the samples were oven dried at $105^{\circ} \mathrm{C}$ for 24 hours. Munktell 132 filters were used for filtration, and for determination of plant available $\mathrm{P}$ and $\mathrm{K}$, Munktell 131 filters were used.

Soil samples were sieved $(<2 \mathrm{~mm})$. Soil $\mathrm{pH}$ and $\mathrm{pH}$ of the sediments was measured in $0.01 \mathrm{M} \mathrm{CaCl}_{2}$. Plant available $\mathrm{P}$ and $\mathrm{K}$ were determined by using a citric-lactate-acetate-extraction and measured with ICP-OES (Thermo ICAP 6000 Series) and partly with AAS in the case of K (AnalyticJena novAA 400; $\mathrm{K}=769.8$ $\mathrm{nm})$. Effective cation exchange capacity $\left(\mathrm{CEC}_{\mathrm{eff}}\right)$ was determined in $0.5 \mathrm{M}$ ammonium chloride. Cation concentrations of the extracts were measured using ICP-OES, except for sodium $(\mathrm{Na})$, which was measured with the AAS $(\mathrm{Na}=589.5 \mathrm{~nm})$. The base saturation was calculated by the sum of the cations $\mathrm{K}$, magnesium $(\mathrm{Mg}), \mathrm{Na}$, and $\mathrm{Ca}$ divided by the $\mathrm{CEC}_{\text {eff }}$ times 100 .

For further chemical analysis, the soil samples were ground with a ball mill. Total organic $\mathrm{C}, \mathrm{N}$, and sulfur (S) concentrations were determined using a CNS-Analyzer (Elementar Vario EL III). To obtain total concentrations of $\mathrm{P}, \mathrm{K}, \mathrm{Ca}$, and $\mathrm{Mg}, 0.5 \mathrm{~g}$ solid matter was dissolved in $10 \mathrm{~mL}$ aqua regia and heated for 8 hours at $185^{\circ}$ $\mathrm{C}$ in a closed teflon pot. After filtration, the elements were determined by ICP-OES. Household waste samples and all plant samples were ground with a planetary mill. Nitrogen concentrations were determined with the CNS-Analyzer. To determine the concentrations of $\mathrm{P}, \mathrm{K}, \mathrm{Mg}$, and $\mathrm{Ca}, 250 \mathrm{mg}$ of plant material were added to $5 \mathrm{~mL}$ nitric acid, and $100 \mathrm{mg}$ of ash to $10 \mathrm{~mL}$, respectively, in the case of the ash. The solution was heated for 8 hours at $185^{\circ} \mathrm{C}$ in a closed teflon pot and then filtrated. Measurement was done with ICP-OES.

To obtain a total overview of the household's nutrient fluxes, all missing data was complemented by means of literature-derived data and explicitly stated (see Tables 1 and 2). So as to respect the local family, feces and urine were not sampled. The total nutrient amount of feces, urine, and greywater was assumed to be similar to ingestion and was therefore approximated by the consumption of food (Table 2). Nitrogen concentration was derived by multiplying protein concentrations times food specific factors proposed by Mariotti et al. (2008).

\section{Calculations of nutrient fluxes}

Parameters describing nutrient dynamics, like leaching and erosion of the study field soil, were taken from literature, if literature data was available and could be compared. Soil erosion was estimated by comparing erosion signs at the farmland with data of erosion in shifting cultivation systems in tropical agroforestry collected by Wiersum (1984). It was finally multiplied times the nutrient difference between the upper layer and the soil below. Leaching of $\mathrm{P}$ was approximated with data of a fertilized sandy clay loam in Brazil (Blum et al. 2013). In the case of K, leaching was calculated by an equation developed by FAO (2003) including plant available $\mathrm{K}$ of the first $20 \mathrm{~cm}$ and a factor $\mathrm{F}$ depending on precipitation (PRC) and clay concentration:

$$
\mathrm{K}_{\text {leaching }}=\mathrm{K}_{\text {available }} * \mathrm{~F}(\mathrm{PRC} \text {, clay concentration })
$$

According to Blum et al. (2013), N leaching can be estimated by considering the total $\mathrm{N}$ input by fertilizers (here zero) and the rainfall. Based on that, $\mathrm{N}$ leaching was estimated by comparison 
Table 1. Total nutrient concentrations of substances used and produced in the household. Part of the values were derived by own analysis $(n=2)$, the other values were taken from literature. All moisture data was taken from literature, indicated by references and superscripts below.

\begin{tabular}{|c|c|c|c|c|c|}
\hline & $\begin{array}{c}\text { Moisture } \\
\%\end{array}$ & $\begin{array}{c}\mathrm{N}_{\mathrm{tot}} \\
\mathrm{mg} / \mathrm{kg}\end{array}$ & $\begin{array}{c}\mathrm{K}_{\mathrm{tot}} \\
\mathrm{mg} / \mathrm{kg}\end{array}$ & $\begin{array}{c}\mathrm{P}_{\mathrm{tot}} \\
\mathrm{m} / \mathrm{kg}\end{array}$ & References \\
\hline \multicolumn{6}{|c|}{ Food supply, edible portion } \\
\hline Cassava & 60 & 3644 & 6775 & 675 & USDA $2015 a$ \\
\hline Fish & 80 & 146774 & 17900 & 10450 & USDA $2015 b$ \\
\hline Plantain & 65 & 6633 & 14257 & 971 & USDA $2015 c$ \\
\hline Lentils & 8.26 & 48114 & 7380 & 3063 & USDA $2015 d$ \\
\hline Rice & 12.89 & 14210 & 987 & 1240 & USDA $2015 e$ \\
\hline Eggs & 76.15 & 92716 & 5786 & 8302 & USDA $2015 f$ \\
\hline \multicolumn{6}{|l|}{ Nonedible food portion } \\
\hline Plantain peel & $82.9^{1}$ & $14162 \pm 236$ & $66372 \pm 1670$ & $2424 \pm 22$ & own analysis \\
\hline Cassava peel & $72.1^{2}$ & 9786 & 2912 & 1671 & Akpabio et al. 2012 \\
\hline Residue of asua & $0.9^{3}$ & $4791 \pm 16$ & $10023 \pm 81$ & $916 \pm 33$ & own analysis \\
\hline Fish meal & $6^{4}$ & 130357 & 6051 & 44374 & Dale 2001 \\
\hline Egg shells & $0.1^{5}$ & 3750 & 416 & 993 & Hincke et al. 2012 \\
\hline \multicolumn{6}{|l|}{ Wood and wood residues } \\
\hline Firewood & $53^{6}$ & $1436 \pm 47$ & $156 \pm 11$ & $59 \pm 3$ & own analysis \\
\hline Ash & & $294 \pm 22$ & $111405 \pm 316$ & $8697 \pm 46$ & own analysis \\
\hline Coal & & $2562 \pm 803$ & $5455 \pm 148$ & $1600 \pm 40$ & own analysis \\
\hline Sawdust & $53^{6}$ & $1436 \pm 47$ & $156 \pm 11$ & $59 \pm 3$ & own analysis \\
\hline \multicolumn{6}{|l|}{ Waste water } \\
\hline Urin $^{\dagger}$ & & 87 & 54 & 50 & Jönsson et al. 2004 \\
\hline Feces $^{\dagger}$ & & 10 & 12 & 40 & Jönsson et al. 2004 \\
\hline
\end{tabular}

${ }^{1}$ Izonfuo and Omuaru $1988 ;{ }^{2}$ Akpabio et al. $2012 ;{ }^{3}$ own assumption; ${ }^{4}$ Dale $2001 ;{ }^{5}$ Nys et al. 2011; ${ }^{6}$ Suzuki 1999.

$+=\%$ of total nutrient value of the household waste water.

with a long-term study conducted in a comparable climate zone, the subtropics in China (Long et al. 2015):

$\mathrm{N}_{\text {leaching }}=\mathrm{N}_{\text {leaching,China }} / \mathrm{PRC}_{\text {China }} * \mathrm{PRC}_{\text {Sarayaku }}$

Data for deposition of nutrients was taken from a study conducted in the south of Ecuador as an example for the deposition of nutrients in the eastern Andes (Boy et al. 2008). Rates of Nfixation were taken from data sampled by FAO (2003), as well as denitrification depending on precipitation. Run-off data was taken from a study of cassava crop fields conducted in the Andean region of Colombia (R. H. Howeler 2001, unpublished manuscript, http://citeseerx.ist.psu.edu/viewdoc/download?

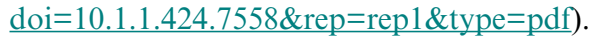

Although some recycled nutrients would not be plant available in the first year, we argue that it makes sense to calculate with total nutrient concentrations, given the importance of long-term orientation. For the nutrient balance of all scenarios, a hypothetic soil amendment share of $50 \mathrm{vol} \%$ biochar and $5 \mathrm{vol} \%$ clayey sediment of the compost was calculated, as performed by Schulz and Glaser (2012) and by Bölttcher et al. (2013), respectively. The density of the compost was approximated as $700 \mathrm{~kg} \mathrm{~m}^{-3}$ by comparing with the results of Krause et al. (2015). To calculate the nutrient demand for the tree plantation, we analyzed the required amount of wood for cooking and biochar production and multiplied that with the nutrient concentrations of the analyzed sawdust.

By means of simplification, any child was calculated as a half adult. All calculations related to farmland, field, or soil refer to one farm of the participating family, which is located near the hamlet and covers $0.42 \mathrm{ha}$. The balance at the farmland is given by the equation:
Farmland $=$ input - output $\pm \Delta$ soil $[\mathrm{g} /$ capita $*$ a $]$

where input is the sum of compost, clay, coal, and human excreta, output is harvest, and $\Delta$ soil refers to the soil dynamic parameters (Fig. 2). All calculations of the scenarios were calculated per person, which means that the field of 0.42 ha was split into 5.5 portions (the number of persons of the participating family), leading to an area of $764 \mathrm{~m}^{2}$ for each person. If not explicitly stated, all data is related to dry matter.

Fig. 2. Soil nutrient dynamics $\left[\mathrm{kg} / \mathrm{ha} \mathrm{a}^{-1}\right]$ of the investigated farmland without human activities, like harvesting or fertilization. Their calculation is based on data taken from the following literature: ${ }^{1}$ Boy et al. 2008; ${ }^{2} \mathrm{FAO} 2003$; ${ }^{3}$ estimated according to Wiersum 1984; ${ }^{4}$ Long et al. 2015; ${ }^{5}$ Blum et al. 2013; ${ }^{6}$ Howeler 2001.

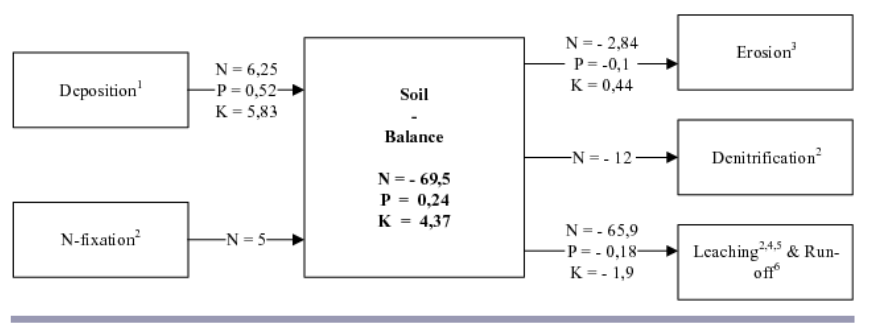

\section{Model and scenarios}

Five different scenarios of nutrient cycles were established and balanced based on extrapolation of the results of the field survey, laboratory analyses, and information from literature (Table 3). The first three scenarios were based on the present condition in Sarayaku, in which wood is easily available, which is presumed to 
Table 2. Household nutrient fluxes and the amount of food consumption, human excreta, and household waste. Own analysis was complemented by literature, indicated by the superscripts below.

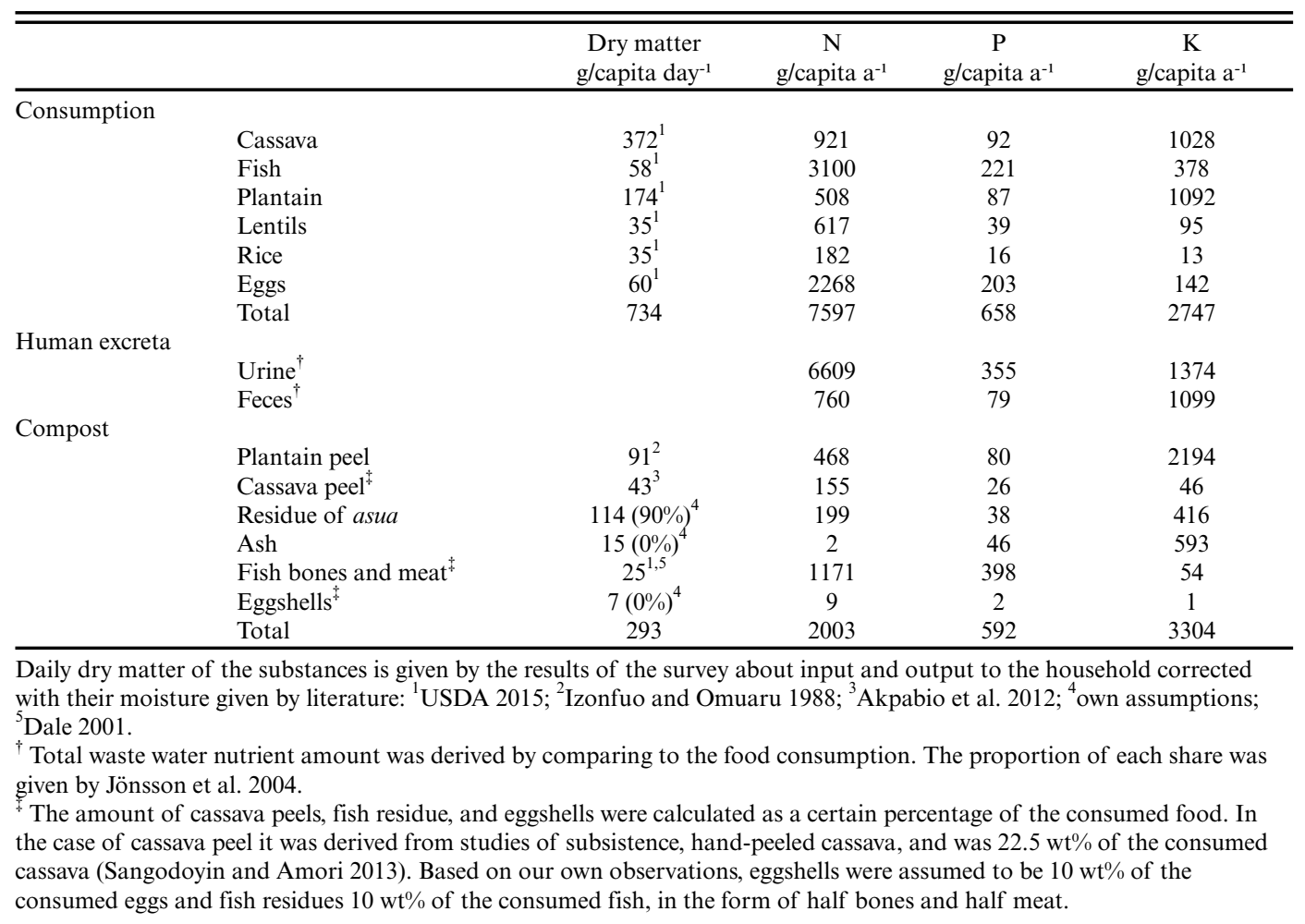

Table 3. Scenarios considered in this study: The first scenario recycles all household wastes without human excreta. Scenario II additionally includes urine, and scenario III, both urine and feces. Scenarios IV and V differ from the third in the way of producing the wood in form of a tree plantation. Scenario IV also recycles the feces, but only to fertilize the tree plantation, rather than in the cropping system, the main aim of which is to avoid hygienic risks. Scenario $\mathrm{V}$ includes feces at the tree plantation and at the farmland, by integrating feces in the compost.

\begin{tabular}{lcccc}
\hline \hline & $\begin{array}{c}\text { Household } \\
\text { waste }\end{array}$ & Urine & Feces & $\begin{array}{c}\text { Tree } \\
\text { plantation }\end{array}$ \\
\hline Scenario 1 & $\mathrm{X}$ & & & \\
Scenario 2 & $\mathrm{X}$ & $\mathrm{X}$ & & \\
Scenario 3 & $\mathrm{X}$ & $\mathrm{X}$ & $\mathrm{X}$ & \\
Scenario 4 & $\mathrm{X}$ & $\mathrm{X}$ & $(\mathrm{X})$ & $\mathrm{X}$ \\
Scenario 5 & $\mathrm{X}$ & $\mathrm{X}$ & $\mathrm{X}$ & $\mathrm{X}$ \\
\hline
\end{tabular}

be similar in most indigenous communities of the Amazonian rain forest. They vary in the integration of human excreta and show consequently the different nutrient recycling potential (Fig. $3)$. The other two scenarios integrate the production of wood and therefore do not depend on external wood sources (Fig. 4). Firewood, fishery, and purchase of external food are referred to as external input in the scenarios I to III. Nutrient amount of the tree plantation is given by the demand for firewood and coal. The required nutrients come from the feces (scenario IV) or the compost (scenario V).
Fig. 3. Scenarios I, II, and III: As input to the household are shown the nutrients from the farmland and the external input of nutrients to the household by the forest, the fishery, and the purchase of external food (given by neighbors or bought as groceries). All household waste with the exception of human excreta are proposed to be composted with coal and river clay. Part of these scenarios is the input of wood for cooking and coal production with external wood, as is customary in Sarayaku. Although in scenario I no human excreta is recycled, scenario II involves human urine (dotted line) and scenario III, both human urine and feces (dashed and dotted line).

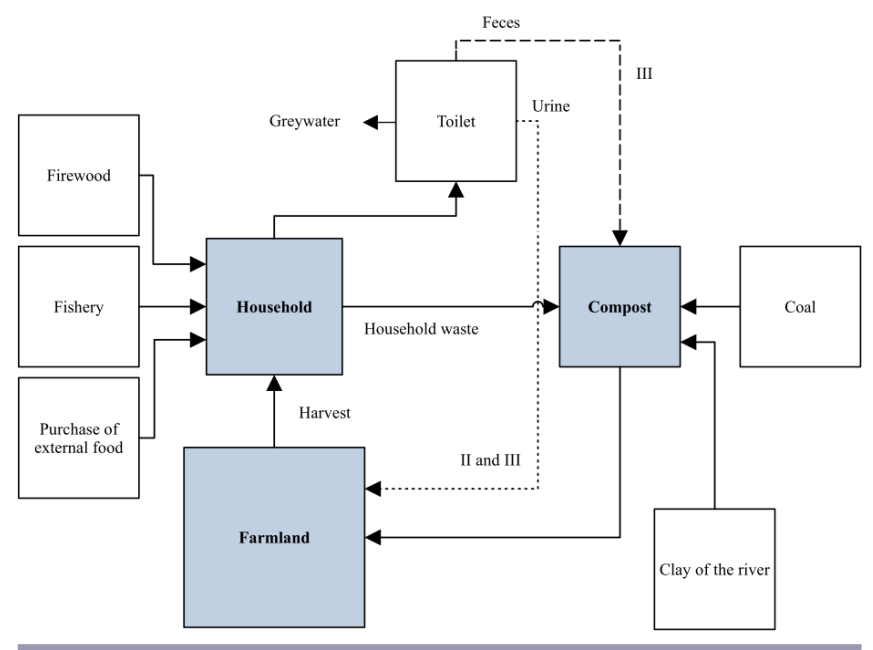


Fig. 4. Scenario IV and V: In these scenarios a tree plantation is integrated in order to produce firewood and coal, which allow independence from external wood resources. Therefore, only the fishery and purchase of external food integrate external nutrients into the system. In scenario IV, feces are used as nutrient input for the tree plantation (dashed line). In constrast, scenario $\mathrm{V}$ includes feces only in the compost, and the tree plantation is fertilized by a certain portion of it (dotted line).

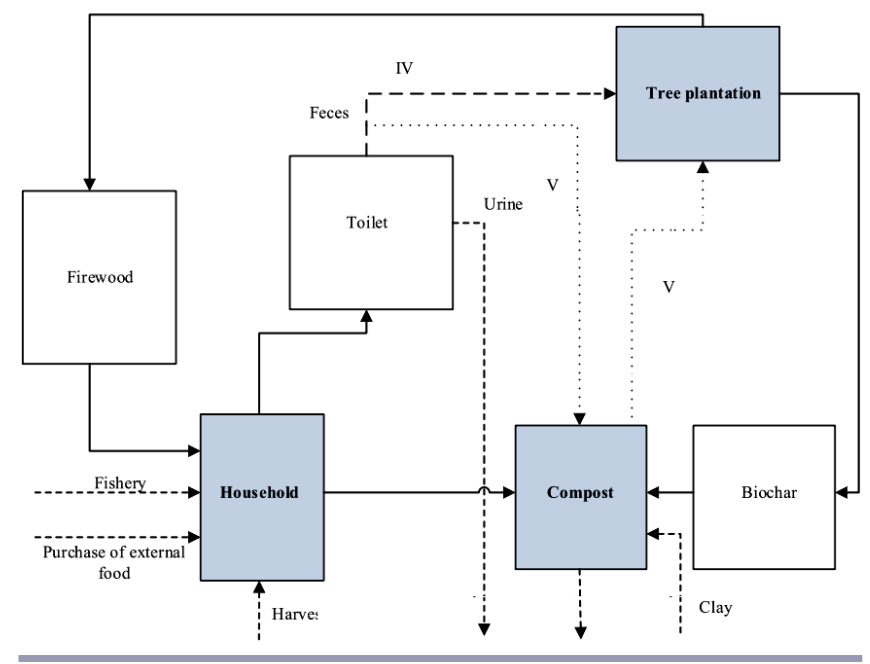

\section{RESULTS}

Main features of the case study

The participating family has four adult members and three children. One of the adults earns a small amount of extra cash income by working for the community on the reforestation of palms for rooftop construction and special trees. They usually buy small amounts of food in a little shop in the village or from neighbors, including lentils, rice, eggs, oil, meat, and fish as is custom in Sarayaku (see also Sirén and Machoa 2008). In the morning, family members usually only drink the fermented beverage asua, made of cassava, and later on the day they cook. Asua is one of the major food sources, especially when other food is rare. As is common for the investigated region, the residue of the food is not composted but thrown out of the kitchen and partly eaten by poultry and dogs of the neighbors. The family cultivates currently two farms of 0.42 and 0.105 ha. A small pathway uphill passes by the bigger farm, which is located on the hillside about one $\mathrm{km}$ away from the village, and it was cleared and burned in August 2014. The smaller one is about $3 \mathrm{~km}$ away from the hamlet, on top of the same hill and was cleared and burned one year before. On both farm, mostly cassava is cultivated, followed by plantain and a few flowers, other fruits, and root-crops at less than $10 \%$ of all crops. The soil is sandy clay that contains at least $35 \%$ clay and a minimum of $45 \%$ sand. The closer farm, which covers 0.42 ha, was considered suitable as permanent farmland because it is located outside the river flood plain, but still close to the hamlet. That is why all further calculations referring to farmland and its soil refer to the abovementioned farmland.

\section{Nutrient concentration of soil and river sediments}

The $\mathrm{pH}$ of the sediments is almost neutral, while acidic in the farmland (Table 4). Both sediments have higher total K, P, Ca, and $\mathrm{Mg}$ concentrations and lower $\mathrm{S}$ and $\mathrm{C}$ concentrations than the farmland at each depth. The clayey sediment shows the highest concentration for almost all nutrients. It has more than 10 times more $\mathrm{Ca}, 7$ times more $\mathrm{Mg}, 5$ times more $\mathrm{K}$, and 2 times more $\mathrm{P}$ than the farmland at both depths. The clayey river sediment contains the highest concentrations of plant available $\mathrm{K}$, followed by the first $20 \mathrm{~cm}$ of the farmland. Plant available $\mathrm{P}$ was detected in the following order from highest to lowest concentration: in the clayey sediment, the first $20 \mathrm{~cm}$ at the farmland, the sandy sediment, and the farmland's soil between 20 and $40 \mathrm{~cm}$. The $\mathrm{CEC}_{\text {eff }}$ of the clayey sediment is more than four times larger than that of the farmland and sandy sediment. Compared to the farmland, the base saturation of both sediments is very high.

Table 4. Total nutrient concentrations, $\mathrm{pH}$, plant available $\mathrm{K}$ and $\mathrm{P}$, effective cation exchange capacity $\left(\mathrm{CEC}_{\mathrm{eff}}\right)$, and base saturation (BS) of the farmland and the river sediments. Number of analyzed samples was $n=2$, with the exception of $\mathrm{pH}$ and $\mathrm{BS}(\mathrm{n}=1)$.

\begin{tabular}{lccccc}
\hline \hline & Unit & $\begin{array}{c}\text { Sandy river } \\
\text { sediment }\end{array}$ & $\begin{array}{c}\text { Clayey river } \\
\text { sediment }\end{array}$ & $\begin{array}{c}\text { Farmland } \\
0-20 \mathrm{~cm}\end{array}$ & $\begin{array}{c}\text { Farmland } \\
20-40 \mathrm{~cm}\end{array}$ \\
\hline $\mathrm{N}_{\text {tot }}$ & $\mathrm{mg} / \mathrm{kg}$ & $133 \pm 1$ & $1020 \pm 6$ & $2199 \pm 19$ & $1176 \pm 3$ \\
$\mathrm{P}_{\text {tot }}$ & $\mathrm{mg} / \mathrm{kg}$ & $154 \pm 1$ & $339 \pm 1$ & $133 \pm 8$ & $96 \pm 1$ \\
$\mathrm{~K}_{\text {tot }}$ & $\mathrm{mg} / \mathrm{kg}$ & $3185 \pm 37$ & $10743 \pm 4$ & $2093 \pm 50$ & $2249 \pm 14$ \\
$\mathrm{C}_{\text {tot }}$ & $\mathrm{mg} / \mathrm{kg}$ & $764 \pm 49$ & $11216 \pm 38$ & $23132 \pm 151$ & $9675 \pm 39$ \\
$\mathrm{Ca}_{\text {tot }}$ & $\mathrm{mg} / \mathrm{kg}$ & $3832 \pm 1$ & $7538 \pm 1$ & $560 \pm 8$ & $321 \pm 1$ \\
$\mathrm{Mg}_{\text {tot }}$ & $\mathrm{mg} / \mathrm{kg}$ & $2816 \pm 26$ & $8572 \pm 46$ & $1286 \pm 3$ & $1362 \pm 3$ \\
$\mathrm{~S}_{\text {tot }}$ & $\mathrm{mg} / \mathrm{kg}$ & $52 \pm<0.1$ & $158 \pm 17$ & $280 \pm 2$ & $160 \pm 0,3$ \\
$\mathrm{pH}$ & & 6.11 & 5.98 & 4.05 & 3.92 \\
$\mathrm{~K}_{\text {aacl2 }}$ & $\mathrm{mg} / \mathrm{kg}$ & $10 \pm 3$ & $59 \pm 1$ & $51 \pm 2$ & $10 \pm 1$ \\
$\mathrm{P}_{\text {avail. }}$ & $\mathrm{mg} / \mathrm{kg}$ & $1.5 \pm<0.1$ & $8.6 \pm<0.1$ & $4.3 \pm<0.1$ & $0.6 \pm<0.1$ \\
$\mathrm{CEC}_{\text {eff. }}$ & $\mathrm{cmolc} / \mathrm{kg}$ & $3.23 \pm 0.1$ & $21.98 \pm 0.3$ & $4.26 \pm 0.1$ & $4.33 \pm 0.1$ \\
$\mathrm{BS}$ & $\%$ & 97.3 & 99.5 & 42.3 & 19.0 \\
\hline
\end{tabular}

\section{Nutrient balance of the soil}

The total nutrient stock at the farmland in the first $40 \mathrm{~cm}$ is 6615 $\mathrm{kg} \mathrm{N} \mathrm{ha}{ }^{-1}, 447 \mathrm{~kg} \mathrm{P} \mathrm{ha}^{-1}$, and $8511 \mathrm{~kg} \mathrm{~K} \mathrm{ha}^{-1}$. Soil erosion was estimated as moderate with an erosion potential of $2.78 \mathrm{t} / \mathrm{ha}$, as a result of no tillage practice, low erosion signs (no water channels, a moderate hillslope of around 5\%, and still litter lying aboveground) but low soil cover by plants, which intensifies erosion (compare to Wiersum 1984). Overall nutrient dynamics of the farmland after burning, but without further human activity, are negative in the case of $\mathrm{N}$ and positive for $\mathrm{P}$ and $\mathrm{K}$ (Fig. 2).

\section{Fate and concentration of household nutrients}

The main food consumed by the family was plantain and cassava, the latter in the form of asua. Approximately half of the cooked meals were complemented by fish, and half with eggs. The most important food supply for K was cassava and plantain. Fish and eggs appeared to be the most important supply of $\mathrm{P}$. The quantitative summary of the food supply is similar to another study made in Sarayaku (Table 5).

The residue of the food was, in order of the accruing amount, residue of asua, plantain peel, cassava peel, fish bones and meat, ash, and eggshells. The largest amount of $\mathrm{K}$ per capita and year was detected in plantain peel and urine, in the case of $P$ in urine and fish bones and meat. The highest amount of nitrogen was detected in urine, fish bones and meat, and feces (Table 2). 
Table 5. Food supply in kg/capita day ${ }^{-1}$; raw material. Comparison between present study and another study made in Sarayaku.

\begin{tabular}{lcc}
\hline \hline & Present study & Sirén and Machoa 2008 \\
\hline Cassava & 1.03 & 1.55 \\
Fish/wild/eggs & 0.64 & 0.34 \\
Plantain & 0.83 & 0.72 \\
Total & 2.50 & 2.62 \\
\hline
\end{tabular}

\section{Nutrient balance of the scenarios}

Scenarios II to $\mathrm{V}$ are able to accumulate $\mathrm{N}, \mathrm{P}$, and $\mathrm{K}$ at the farmland (Table 6). Scenario I shows lack of N and K. Scenario $\mathrm{V}$ shows a higher accumulation of all considered nutrients than scenario IV (Table 6). Compared to I, the additional nutrient recycling is, in order of scenarios II to $\mathrm{V}, 420,466,420$, and $413 \%$ for nitrogen, 170, 203, 170, and $180 \%$ for phosphorus, and 157 , 178,157 , and $158 \%$ for potassium.

\section{DISCUSSION}

Considering the results, this case study shows that it is feasible to accumulate nutrients at the farmland as a prerequisite for generation of permanent farmland by combining knowledge of TPP and the way of life of indigenous communities. Prolonging crop periods or substitution of slash-and-burn-practice seem possible.

\section{Utilization of river sediments}

The clayey sediment showed good results in nutrient concentration, alkalinity, and $\mathrm{CEC}_{\text {eff }}$ and might, thus, be useful to enhance the composting process. Other river sediments, located near Sarayaku, showed similar concentrations of exchangeable basic cations (Martinelli et al. 1993). The closer the sediments are to the Andes, from where the Amazon rivers carry plutonic, nutrient rich material downstream, the higher their percentage of illites and smectites (clay minerals with a high $\mathrm{CEC}_{\text {eff }}$; Guyot et al. 2007). The high $\mathrm{pH}$ of the analyzed sediments could have a positive impact on soil acidity and reduce Al-toxicity, increase $\mathrm{P}$ availability and activity of microorganisms when added to the soil (Giardina et al. 2000). The higher concentration of some nutrients compared to the soil of the farmland could also improve nutrient status. Furthermore, the high $\mathrm{CEC}_{\text {eff }}$ of the clayey sediment leads to increased adsorption capacity to $\mathrm{K}$ and ammonium. However, concentrations of available $\mathrm{K}$ and $\mathrm{P}$ of both sediments were only slightly higher than those of the upper layer of the farmland's soil and seem therefore not suitable as soil amendment. To generate real impact by adding sediment to the farmland, the amount needed would thus be tremendous. In a study pertaining to the lowlands of Colombia, Herrera et al. (1992) calculated a requirement of $245 \mathrm{t} / \mathrm{ha}^{-1} \mathrm{a}^{-1}$ river sediment to significantly increase soil fertility. It seems unlikely that this could be done by hand and therefore it could be considered futile with respect to farmlands out of the flood plains. Local farmers prefer sandy instead of clayey patches for planting in the flood plains, because of an improved soil structure, leading to better permeability for water and easier workability. However, in the creation of persistent soil organic matter, clay could play a major role. In the composting process, organic matter can interact with clayminerals and create clay-humus-complexes, enhancing soil fertility (Evans and Russel 1959) and nutrient retention (Nguyen and Marschner 2013). In conclusion, mixing clay with compost is most likely to result in a positive impact and its implementation does not require too much effort.

\section{Nutrient dynamics of the soils}

When comparing total nutrient stock at the farmland with the annual output through soil dynamics without human activity, the accumulation of $\mathrm{P}$ and $\mathrm{K}$ is far lower than $1 \%$, and only in the case of $\mathrm{N}$ with a loss of $1.1 \%$ it shows significant change to the nutrient status. The results of the nutrient dynamics are mostly based on literature and are not satisfactorily fitting in all cases, especially pertaining to leaching of $\mathrm{N}$.

Nutrient dynamics of the farmland's soil were calculated without further human changes like the added compost, although nutrient leaching from these amendments is likely. The precise values were not further investigated, but some possible changes shall be discussed. Whereas Schulz and Glaser (2012) detected increased leaching of phosphorus and nitrogen in the first year after application of compost and biochar, other studies have shown decreased leaching of $\mathrm{N}$ (Lehmann et al. 2003b) and of $\mathrm{P}$ (Agegnehu et al. 2015). The recalcitrant biochar might remain in the soil for centuries and lead to better nutrient and water holding capacity (Verheijen et al. 2010). When the biochar is annually given as a part of the compost to the farmland, it would be a small amount relative to the soil in the early years. Thus, the nutrient leaching of the urine, as liquid fertilizer, may be high because of the still low $\mathrm{CEC}_{\text {eff }}$ of the soil. Erosion could potentially become a problem, if the upper layer of the permanent farmland, enriched with compost and urine, erodes and reveals the unimproved soil below. However, biochar and vermicompost (composting with worms) as soil amendment have shown decreased erosion and run-off (Thu Doan et al. 2015). In conclusion, parts of the nutrients might be lost after their addition to the field and the balances might be affected negatively. However, in the long run carbon content and sorption capacity should improve through repeated amendment of biochar and other resilient organic matter from the compost. The nutrient dynamics of the tree plantation's soil were not further investigated. It was assumed to be low in nutrient losses because of the almost undisturbed plant situation and soil cover (see also Vitousek and Sanford 1986).

\section{Household nutrients and composting}

High amounts of $\mathrm{P}$ and $\mathrm{N}$ were contributed by fish and eggs. Potassium was mostly given by plantain and cassava. If nutrient supplies by fishing decrease, the balance could, thus, become negative. This could be compensated by introducing poultry, increasing farm yield, or other food supply.

Only one family's nutrition was investigated in this study, and the family was not randomly chosen. The short sample period could furthermore increase errors by seasonal bias. One deviation was the fact that the family hunted less frequently than an average family in Sarayaku (see also Sirén and Machoa 2008). With regard to Sirén and Machoa (2008), the consumption of wild game corresponds to about one quarter of the consumption of fish. The nutrient composition of wild game is similar to fish for $\mathrm{N}$ and $\mathrm{K}$, but less in P (USDA 2015b, 2019), so that the investigated family might have a slightly higher input of $P$ than others. Because the balance of $\mathrm{P}$ is very positive in all scenarios, this would not prevent its accumulation on the farmland (see Table 5). 
Table 6. Nutrient cycling balance of all scenarios [g/capita $\left.\mathrm{a}^{-1}\right]$.

\begin{tabular}{|c|c|c|c|c|c|c|c|c|c|}
\hline & \multicolumn{3}{|c|}{$\mathrm{N}$} & \multicolumn{3}{|c|}{$\mathrm{P}$} & \multicolumn{3}{|c|}{$\mathrm{K}$} \\
\hline & input & & output & input & & output & input & & output \\
\hline \multicolumn{10}{|l|}{ Scenario 1} \\
\hline Harvest & & & -2196 & & & -343 & & & -4413 \\
\hline soil dynamics & 859 & & -6168 & 40 & & -22 & 446 & & -112 \\
\hline Compost & 2003 & & & 592 & & & 3304 & & \\
\hline Clay & 10 & & & 3 & & & 103 & & \\
\hline Biochar & 51 & & & 32 & & & 108 & & \\
\hline Total & & -5442 & & & 302 & & & -566 & \\
\hline \multicolumn{10}{|l|}{ Scenario 2} \\
\hline Scenario 1 & & -5442 & & & 302 & & & 566 & \\
\hline Urine & 6609 & & & 355 & & & 1374 & & \\
\hline Total & & 1167 & & & 658 & & & 808 & \\
\hline \multicolumn{10}{|l|}{ Scenario 3} \\
\hline Scenario 2 & & 1167 & & & 658 & & & 808 & \\
\hline Feces & 760 & & & 79 & & & 1099 & & \\
\hline Total & & 1927 & & & 736 & & & 1907 & \\
\hline \multicolumn{10}{|l|}{ Scenario 4} \\
\hline Scenario 3 & & 1927 & & & 736 & & & 1907 & \\
\hline $\begin{array}{l}\text { Tree plantation, } \\
\text { feces fertilized }\end{array}$ & & & -760 & & & -79 & & & -1099 \\
\hline Total & & 1167 & & & 658 & & & 808 & \\
\hline \multicolumn{10}{|l|}{ Scenario 5} \\
\hline Scenario 3 & & 1927 & & & 736 & & & 1907 & \\
\hline $\begin{array}{l}\text { Tree plantation, } \\
\text { compost fertilized }\end{array}$ & & & -485 & & & -50 & & & -284 \\
\hline Total & & 1442 & & & 686 & & & & \\
\hline
\end{tabular}

C/N-ratio of the compost would drop to around four in all scenarios, resulting in mobilization and loss of $\mathrm{N}$ (e.g., by leaching and volatilization), if the urine would be added to the compost. Without urine, the resulting ratios of the compost were between 17 and 22 in the scenarios II to IV and were therefore still below the optimal ratio of $\mathrm{C} / \mathrm{N}$ equal to 25 (Finck 2007). Only scenario $\mathrm{V}$ showed a higher $\mathrm{C} / \mathrm{N}$-ratio of 32 . The low $\mathrm{C} / \mathrm{N}$-ratio of the other scenarios could be managed by addition of $\mathrm{C}$-rich materials like sawdust or rotten wood. As mentioned, the by-production of sawdust is rare or very work intensive in Sarayaku. Rotten wood would need to be carried from the forest. Thus, application of urine as liquid fertilizer for crops seems preferential to secure $\mathrm{N}$ availability for the crops, other than the addition of urine to the compost. However, direct fertilization could increase volatilization of ammonia, which should be decreased by fast incorporation of the urine into the soil (Sommer and Hutchings 2001).

Leaching and volatilization of nutrients during the compost procedure were not calculated as part of the balances because it depends greatly on the design of the composting process (Hao and Benke 2008) and was therefore difficult to predict. However, especially in the case of nitrogen, it is most likely to affect the balances negatively.

\section{Evaluation of the scenarios}

All scenarios (except for scenario I) exhibit potential to accumulate nutrients at the farmland. Scenario III is the best with respect to the overall quantity of recycled nutrients. The integration of human excreta, at least urine, is necessary for a positive nutrient balance. Furthermore, recycling both urine and feces leads to a better nutrient recycling, even though feces contribute less nutrients than urine. Regarding the nutrient amounts, scenarios IV and V are only slightly different to each other. Also, others, especially the high nutrient input by fish and eggs, result in the positive balance of the scenarios.

The lack of $\mathrm{N}$ in the first scenario could be compensated by intercropping with leguminous plants. Pulses, like soybeans, which also grow in the tropics and are important dietary components, are able to incorporate atmospherical $\mathrm{N}$ into the soil through symbiosis with bacteria (Döbereiner 1997). Salvagiotti et al. (2008) detected an $\mathrm{N}$ intake of $129 \mathrm{~kg} \mathrm{ha}^{-1} \mathrm{a}^{-1}$ into the soil when $100 \mathrm{~kg} \mathrm{ha}^{-1} \mathrm{a}^{-1} \mathrm{~N}$ was additionally applied as fertilizer. In contrast, $\mathrm{K}$ requires external sources. Considering that, scenario I does not seem to be able to facilitate permanent farmland. Instead, Scenario II seems particularly suitable because of its accumulation of nutrients and its low hygienic risks.

Both scenarios with tree plantation have their special advantages. Although scenario V shows more accumulation of $\mathrm{N}, \mathrm{P}$, and $\mathrm{K}$, scenario IV has the benefit of a lower hygienic risk. The feces could be sampled, dried separately, and fertilize the tree plantation, e.g., the trees could be planted on top of the buried feces. In this way the recycling of the feces could be managed with less risk of hygienic problems than by fertilizing the crops with it or its integration into compost. Although hygienization of feces through composting is an approved method (Heinonen-Tanski and van Wijk-Sijbesma 2005, Krause et al. 2015), it could increase hygienic problems in the case of Sarayaku. Most likely, the compost would be located near the house and insects might cross the compost and the household and thus spread pathogens. In order to avoid diseases, scenario III and V should only be implemented under scientific monitoring. In discussions about the reuse of feces for agriculture in Sarayaku, the idea was always rejected by locals, for the very reason of diseases in the past because of bad treatment of human excreta. 
Situated in a huge, intact rain forest, the external input of wood does not seem to pose a problem in Sarayaku. However, in other communities the situation could be different. Even in Sarayaku present conditions could change as population grows or by expropriation through government or private companies. Furthermore, the consequences of disturbing the rain forest near indigenous communities through tree harvesting remain unclear (Sirén 2014). When crop periods are extended because of the application of a scenario, less shifting of farmlands will be necessary, leading to less fallow periods and more space for tree plantations. Despite the limitations, this concept shows potential to improve resilience and sustainability for subsistence farming far beyond Sarayaku as many indigenous communities who have gotten access to markets and/or have settled down permanently confront similar problems (Sirén 2007).

Comparing the scenarios with substances found in TP soils, like bone material and excreta (Glaser and Birk 2012), the third scenario including excreta and bone material from household waste seems to be the closest with respect to its ingredients. However, the comparability to the TP process remains unclear. According to the calculations, it would take approximately 125 years (scenario II) to reach total phosphorous concentrations like those found in the terra preta of $300 \mathrm{mg} / \mathrm{kg}$ (Novotny et al. 2009). Still, it is uncertain whether other macro- and micronutrients accumulate or not. Moreover, food residue, especially from animals, are presently given to poultry and dogs, which seems to contradict the concept.

\section{Practical implementation}

The integration of the compost's nutrients into the land use system demands particular attention for a genuine application of the concept. Within one year, a compost amount of almost $100 \mathrm{~kg}$ per person is produced, and its addition to the upper $20 \mathrm{~cm}$ of the farmland would result in less than $0.1 \mathrm{wt} \%$ compost in the soil. This study thus proposes to mix the compost into the first $20 \mathrm{~cm}$ of the soil near perennial crops with a large nutrient demand, such as plantain, or to mix compost into the soil in special areas for planting new crops. In a step-by-step process to be carried out over time, the compost would be distributed over the whole farmland, whereas some of the very recalcitrant substances might improve the soil for decades, such as biochar and clay-humus-complexes. High yields of $25 \mathrm{t} / \mathrm{ha}$ were obtained in a Colombian cassava field when $150 \mathrm{~kg}$ of $\mathrm{N}$ per year was fertilized (Howeler 2012). Assuming $150 \mathrm{~kg}$ as an appropriate upper limit for $\mathrm{N}$-fertilization, the amount of recycled $\mathrm{N}$ in the case of scenario II could fertilize almost $600 \mathrm{~m}^{2}$ of the permanent farmland. The amount of $\mathrm{K}$ and $\mathrm{P}$ would be 83 and $16 \mathrm{~kg} / \mathrm{ha}$, respectively. To ensure the food demand of the investigated family, $550 \mathrm{~kg}$ harvest is required per year and per person, which corresponds to almost $8 \mathrm{t} \mathrm{ha}^{-1}$, when only $600 \mathrm{~m}^{2}$ would be cultivated. Thus, the permanent farmland requires at least this productivity to become an alternative to the present system. Regarding differences in the soil, exposition, and other parameters, one third of the mentioned yield of $25 \mathrm{t} \mathrm{ha}^{-1}$ might be achievable as total yield of all crops. The present system that yields $2.7 \mathrm{t} \mathrm{ha}^{-1} \mathrm{a}^{-1}$, would thus need to become three times more productive, which seems very ambitious. To reach compost fertilization of at least $1 \mathrm{wt} \%$ of the upper $20 \mathrm{~cm}$ of the soil, 55 $\mathrm{m}^{2}$ could be fertilized by compost per year. In 11 years, the farmland of $600 \mathrm{~m}^{2}$ would be supplied by $1 \mathrm{wt} \%$ compost and biochar. To reduce leaching and volatilization of nutrients, urine should be used to fertilize foremost areas with compost amendment. After a few years, biochar should be distributed over most of the parts of the farmland and the retention of the nutrients of urine should be enhanced over the entire farmland.

To prevent high nutrient loss, a closed compost bin, or at least a protected location situated under a roof or big tree is highly recommended. The residues of asua might enhance the composting process by supplying lacto-fermentation bacteria (see also Vallejo et al. 2013). Furthermore, slash-and-char, or charring the biomass instead of burning, is described as a new method to improve food production, whereas $50 \%$ of the above-ground $\mathrm{C}$ can be converted into charcoal, compared to $1.7 \%$ in the case of slash-and-burn (Fearnside et al. 2001). It can thus be included in the developed scenario in order to improve nutrient retention by charcoal from the outset.

Cultural factors might also influence practical implementation. Although older people were much more skeptical about the concept, especially about reusing human excrement, younger people were more interested. The younger generation is increasingly seeking contact with the capitalist market economy because the subsistence economy is more strenuous than other jobs. The present concept supports the desire to invest less time and energy in field work because it could shorten walking distances and make very time-consuming clearing of fallows unnecessary.

\section{FINAL REMARKS AND PERSPECTIVES}

Recycling nutrients in the proposed scenarios exhibits potential to enhance soil fertility and could improve resilience and sustainability of indigenous communities and subsistence farming in the Amazon. The amendment of clayey sediment can enhance the compost quality and the high $\mathrm{CEC}_{\text {eff }}$ may increase retention of ammonium and $\mathrm{K}$. This might be a good supplement to the biochar, which is foremost able to increase retention of nitrate and $\mathrm{P}$.

Which scenario may be the best depends on the present condition of the agriculture, wood availability, and the willingness and capacity to recycle feces. Regarding the circumstances of Sarayaku, this study proposes scenario II, because of its low risk of pathogen contamination and its potential to generate permanent farmland. The first step of implementation could be to complement common shifting cultivation by gradually increasing permanent farmlands. Depending on the success of the permanent agricultural system, permanent farmland could substitute the slash-and-burn shifting cultivation in a step-by-step process over time.

The treatment of feces, the composting process, and its mixing with the soil of the farmland turned out to be the most complex steps regarding the implementation of the presented scenarios. Eventually, preparing compost and managing of the permanent farmland close to settlements might amount to less work than continuous clearing and preparing fallows with increased walking distances to the farmlands due to population growth linked with rising demand for arable land. Progressive enlargement of fertilized farmlands or gardens near the houses might become the exclusive cropping system. The transferability of the scenarios to other indigenous communities or subsistence farmers is likely, but 
would need further discussion. The proposed scenarios may only with many assumptions be applicable to the whole year or other families. The presented concept might help growing communities to cultivate on less area leading to extended fallow periods with better regeneration of soils and more space for undisturbed rainforest, which probably results in better food production and more hunting success. Furthermore, a sustainable and productive mode of agriculture might contribute to allowing the communities to reach a position in which they can maintain their lifestyle and counteract the ongoing exploitation of natural resources and deforestation.

Ultimately, the question as to whether an applied scenario (II to V) has the chance to create TP and has the possibility to generate permanent farmland demands further field studies, more surveys and long time experiments with focus on practical implementation. To ensure results, further studies of sediment characteristics and their utilization as compost amendment are suggested. Additional studies should analyze nutrient accumulation at the permanent farmland and crop productivity after implementation of scenario II. Surveys about food procurement, especially regarding seasonal differences and other communities, would also be essential.

At first attempts to apply the concept in practice, conducted in March 2016 in Sarayaku, the composting process and the necessary patience until success turned out to be the most critical points hindering implementation. Therefore, long-time experiments with a focus on creating regional models would be necessary to convince indigenous communities to transform their traditional shifting cultivation into permanent cropping systems. Training to learn how to produce biochar and improve composting are, furthermore, essential.

\section{Responses to this article can be read online at: http://www.ecologyandsociety.org/issues/responses. $\mathrm{php} / 11252$}

\section{Acknowledgments:}

We thank Kelly Mulvaney and the anonymous reviewer for their comments. Their efforts greatly improved the manuscript. We would also like to show our gratitude to the technical staff of the Department of Soil Science from the TU for laboratory analyses, to the family Aranda/Santi that participated in the survey, especially Antonio Aranda, our main contact, and to our host family Gualinga. Furthermore, we want to thank all the people of Sarayaku, who were very helpful and hospitable. We wish all the best for their struggle to keep their territory.

\section{LITERATURE CITED}

AG-Boden. 2006. Bodenkundliche Kartieranleitung. KA5. Schweizerbart Science Publishers, Stuttgart, Baden-Württemberg, Germany.

Agegnehu, G., M. I. Bird, P. N. Nelson, and A. M. Bass. 2015. The ameliorating effects of biochar and compost on soil quality and plant growth on a Ferralsol. Soil Research 53(1):1-12. https:// doi.org/10.1071/SR14118
Akpabio, U. D., A. E. Akpakpan, I. E. Udo, and G. C. Nwokocha. 2012. Comparative study on the physicochemical properties of two varieties of cassava peels (Manihot utilissima Pohl). International Journal of Environment and Bioenergy 2(1):19-32.

Batista, E. M. C. C., J. Shultz, T. T. S. Matos, M. R. Fornari, T. M. Ferreira, B. Szpoganicz, R. A. de Freitas, and A. S. Mangrich. 2018. Effect of surface and porosity of biochar on water holding capacity aiming indirectly at preservation of the Amazon biome. Scientific Reports 8:10677. https://doi.org/10.1038/s41598-018-28794$\underline{z}$

Beusch, C., A. Cierjacks, J. Böhm, J. Mertens, W. A. Bischoff, J. C. d. Araújo Filho, and M. Kaupenjohann. 2019. Biochar vs. clay: comparison of their effects on nutrient retention of a tropical Arenosol. Geoderma 337:524-535. https://doi.org/10.1016/j. geoderma.2018.09.043

Blum, J., A. J. Melfi, C. R. Montes, and T. M. Gomes. 2013. Nitrogen and phosphorus leaching in a tropical Brazilian soil cropped with sugarcane and irrigated with treated sewage effluent. Agricultural Water Management 117:115-122. https://doi. org/10.1016/j.agwat.2012.11.010

Böttcher, J., H. Pieplow, and A.-E. Krieger. 2013. Method for the production of humus-and nutrient-rich and water-storing soils or soil substrates for sustainable land use and development systems. United States Patent number 8,465,567 B2. [online] URL: http:// www.google.de/patents/US8465567

Boy, J., R. Rollenbeck, C. Valarezo, and W. Wilcke. 2008. Amazonian biomass burning-derived acid and nutrient deposition in the north Andean montane forest of Ecuador. Global Biogeochemical Cycles 22:4. https://doi.org/10.1029/2007$\underline{\text { GB003158 }}$

Dale, N. M. 2001. Nutrient value of catfish meal. Journal of Applied Poultry Research 10:252-254. https://doi.org/10.1093/ japr/10.3.252

De Gisi, S. D., L. Petta, and C. Wendland. 2014. History and technology of Terra Preta sanitation. Sustainability 6 (3):1328-1345. https://doi.org/10.3390/su6031328

Dempster, D. N., D. L. Jones, and D. V. Murphy. 2012. Clay and biochar amendments decreased inorganic but not dissolved organic nitrogen leaching in soil. Soil Research 50(3):216-221. https://doi.org/10.1071/SR11316

Denevan, W. M. 1996. A bluff model of riverine settlement in prehistoric Amazonia. Annals of the Association of American Geographers 86(4):654-681. https://doi.org/10.1111/j.1467-8306.1996. tb01771.x

Döbereiner, J. 1997. Biological nitrogen fixation in the tropics: social and economic contributions. Soil Biology and Biochemistry 29(5-6):771-774. https://doi.org/10.1016/S0038-0717(96)00226$\underline{\mathrm{X}}$

Evans, L. T., and E. W. Russel. 1959. The adsorption of humic and fulvic acids by clays. European Journal of Soil Science 10 (1):119-132. https://doi.org/10.1111/j.1365-2389.1959.tb00672.x

Fearnside, P. M., P. M. Lima de Alencastro Graca, and F. J. Rodrigues. 2001. Burning of Amazonian rainforests: burning efficiency and charcoal formation in forest cleared for cattle 
pasture near Manaus, Brazil. Forest Ecolgy and Management 146 (1-3):115-128. https://doi.org/10.1016/S0378-1127(00)00450-3

Figueroa, I. 2006. Indigenous people versus oil companies: constitutional control within resistance. Sur - International Journal of Human Rights 4:50-79.

Finck, A. 2007. Pflanzenernährung und Düngung in Stichworten. Borntraeger Gebrueder, Stuttgart, Baden-Württemberg, Germany.

Food and Agriculture Organization (FAO). 2003. Assessment of soil nutrient balance - approaches and methodologies. FAO, Rome, Italy.

Giardina, C. P., R. L. Sanford, I. C. Døckersmith, and V. J. Jaramillo. 2000. The effects of slash burning on ecosystem nutrients during the land preparation phase of shifting cultivation. Plant and Soil 220(1/2):247-260. https://doi. org/10.1023/a:1004741125636

Glaser, B. 2006. Prehistorically modified soils of central Amazonia: a model for sustainable agriculture in the twenty-first century. Philosophical Transactions of the Royal Society B: Biological Sciences 362(1478):187-196. https://doi.org/10.1098/ rstb.2006.1978

Glaser, B., and J. J. Birk. 2012. State of the scientific knowledge on properties and genesis of anthropogenic dark earths in Central Amazonia (terra preta de índio). Geochimica et Cosmochimica Acta 82:39-51. https://doi.org/10.1016/j.gca.2010.11.029

Guyot, J., J. Jouanneau, L. Soares, G. Boaventura, N. Maillet, and C. Lagane. 2007. Clay mineral composition of river sediments in the Amazon Basin. Catena 71(2):340-356. https://doi. org/10.1016/j.catena.2007.02.002

Hao, X., and M. Benke. 2008. Nitrogen transformation and losses during composting and mitigation strategies. Dynamic Soil, Dynamic Plant 2:10-18.

Haug, R. 2015. The practical handbook of compost engineering. CRC, Boca Raton, Florida, USA. https://doi.org/10.1201/9780203736234

Heinonen-Tanski, H., and C. van Wijk-Sijbesma. 2005. Human excreta for plant production. Bioresource Technology 96 (4):403-411. https://doi.org/10.1016/j.biortech.2003.10.036

Herrera, L. F., I. Cavelier, C. Rodríguez, and S. Mora. 1992. The technical transformation of an agricultural system in the Colombian Amazon. World Archaeology 24(1):98-113. https:// doi.org/10.1080/00438243.1992.9980196

Hincke, M. T., Y. Nys, J. Gautron, K. Mann, A. B. RodriguezNavarro, and M. D. McKee. 2012. The eggshell: structure, composition and mineralization. Frontiers in Bioscience 17:1266-1280. https://doi.org/10.2741/3985

Howeler, R. H., editor. 2012. The cassava handbook. A reference manual based on the Asian regional cassava training course, held in Thailand. Centro Internacional de Agricultura Tropical (CIAT), Bangkok, Thailand.

Izonfuo, W.-A. L., and V. O. L. Omuaru. 1988. Effect of ripening on the chemical composition of plantain peels and pulps (Musa paradisiaca). Journal of the Science of Food and Agriculture 45:333-336. https://doi.org/10.1002/jsfa.2740450407
Jönsson, H., A. Richert Stinzing, B. Vinnerås, and E. Salomon. 2004. Guidelines on the use of urine and faeces in crop production. Technical report, Stockholm Environment Institute. EcoSanRes publication series. Stockholm Evironment Institute, Stockholm, Sweden.

Kleinman, P. J. A., R. B. Bryant, and D. Pimentel. 1996. Assessing ecological sustainability of slash-and-burn agriculture through soil fertility indicators. Agronomy Journal 88(2):122-127. https:// doi.org/10.2134/agronj1996.00021962008800020002x

Krause, A., M. Kaupenjohann, E. George, and J. Koeppel. 2015. Nutrient recycling from sanitation and energy systems to the agroecosystem - ecological research on case studies in Karagwe, Tanzania. African Journal of Agricultural Research 10 (43):4039-4052. https://doi.org/10.5897/ajar2015.10102

Lehmann, J., D. Kern, L. German, J. McCann, G. C. Martins, and A. Moreira. 2003a. Soil fertility and production potential. Pages 105-124 in J. Lehmann, D. C. Kern, B. Glaser, and W. I. Woods, editors. Amazonian dark earths: origin, properties, management. Kluwer Academic, Dordrecht, The Netherlands. https://doi.org/10.1007/1-4020-2597-16

Lehmann, J., J. Pereira da Silva Jr., C. Steiner, T. Nehls, W. Zech, and B. Glaser. 2003b. Nutrient availability and leaching in an archaeological Anthrosol and a Ferralsol of the Central Amazon Basin: fertilizer, manure and charcoal amendments. Plant and Soil 249:343-357. https://doi.org/10.1023/a:1022833116184

Long, G.-Q., Y.-J. Jiang, and B. Sun. 2015. Seasonal and interannual variation of leaching of dissolved organic carbon and nitrogen under long-term manure application in an acidic clay soil in subtropical China. Soil and Tillage Research 146:270-278. https://doi.org/10.1016/j.still.2014.09.020

Mariotti, F., D. Tomé, and P. P. Mirand. 2008. Converting nitrogen into protein-beyond 6.25 and Jones' factors. Critical Reviews in Food Science and Nutrition 48(2):177-184. https://doi. org/10.1080/10408390701279749

Martinelli, L. A., R. L. Victoria, J. L. I. Dematte, J. E. Richey, and A. H. Devol. 1993. Chemical and mineralogical composition of Amazon River floodplain sediments, Brazil. Applied Geochemistry 8:391-402. https://doi.org/10.1016/0883-2927(93) 90007-4

Nguyen, T.-T., and P. Marschner. 2013. Addition of a finetextured soil to compost to reduce nutrient leaching in a sandy soil. Soil Research 51(3):232-239. https://doi.org/10.1071/ $\underline{\text { SR } 13105}$

Novotny, E. H., M. H. Hayes, B. E. Madari, T. J. Bonagamba, E. R. de Azevedo, A. A. de Souza, G. Song, C. M. Nogueira, and A. S. Mangrich. 2009. Lessons from the Terra Preta de Índios of the Amazon region for the utilisation of charcoal for soil amendment. Journal of the Brazilian Chemical Society 20 (6):1003-1010. https://doi.org/10.1590/S0103-50532009000600002

Nys, Y., M. Bain, and F. Van Immerseel. 2011. Improving the safety and quality of eggs and egg products. Volume 1: egg chemistry, production and consumption. Woodhead, Cambridge, UK. https:// doi.org/10.1533/9780857093912 
Räsänen, M. E., J. S. Salo, H. Jungner, and L. Romero Pittman. 1990. Evolution of the Western Amazon lowland relief: impact of Andean foreland dynamics. Terra Nova 2:320-332. https://doi. org/10.1111/j.1365-3121.1990.tb00084.x

Salvagiotti, F., K. G. Cassman, J. E. Specht, D. T. Walters, A. Weiss, and A. Dobermann. 2008. Nitrogen uptake, fixation and response to fertilizer N in soybeans: a review. Field Crops Research 108(1):1-13. https://doi.org/10.1016/j.fcr.2008.03.001

Sangodoyin, A. Y., and A. A. Amori. 2013. Aerobic composting of cassava peels using cowdung, sewage sludge and poultry manure as supplements. European International Journal of Science and Technology 2(8):22-34.

Schulz, H., and B. Glaser. 2012. Effects of biochar compared to organic and inorganic fertilizers on soil quality and plant growth in a greenhouse experiment. Journal of Plant Nutrition and Soil Science 175(3):410-422. https://doi.org/10.1002/jpln.201100143

Sirén, A. H. 2004. Changing interactions between humans and nature in Sarayaku, Ecuadorian Amazon. Dissertation. Department of Rural Development and Agroecology, Swedish University of Agricultural Sciences, Sweden.

Sirén, A. H. 2007. Population growth and land use intensification in a subsistence-based indigenous community in the Amazon. Human Ecology 35(6):669-680. https://doi.org/10.1007/s10745-006-9089$\mathrm{y}$

Sirén, A. H. 2012. Festival hunting by the Kichwa people in the Ecuadorian Amazon. Journal of Ethnobiology 32(1):30-50. https://doi.org/10.2993/0278-0771-32.1.30

Sirén, A. H. 2014. History of natural resource use and environmental impacts in an interfluvial upland forest area in Western Amazonia. Fennia - International Journal of Geography 192(1):36-53. https://doi.org/10.11143/8825

Sirén, A. H., and J. Machoa. 2008. Fish, wildlife, and human nutrition in tropical forests: a fat gap? Interciencia 33(3):186-193.

Sommer, S. G., and N. J. Hutchings. 2001. Ammonia emission from field applied manure and its reduction - invited paper. European Journal of Agronomy 15(1):1-15. https://doi. org/10.1016/S1161-0301(01)00112-5

Steiner, C., W. G. Teixeira, J. Lehmann, T. Nehls, J. L. V. de Macêdo, W. E. H. Blum, and W. Zech. 2007. Long term effects of manure, charcoal and mineral fertilization on crop production and fertility on a highly weathered Central Amazonian upland soil. Plant and Soil 291(1-2):275-290. https://doi.org/10.1007/ s11104-007-9193-9

Suzuki, E. 1999. Diversity in specific gravity and water content of wood among Bornean tropical rainforest trees. Ecological Research 14:211-224. https://doi.org/10.1046/j.1440-1703.1999.143301. $\underline{x}$

Thu Doan, T., T. Henry-des-Tureaux, C. Rumpel, J.-L. Janeau, and P. Jouquet. 2015. Impact of compost, vermicompost and biochar on soil fertility, maize yield and soil erosion in Northern Vietnam: a three year mesocosm experiment. Science of the Total Environment 514:147-154. https://doi.org/10.1016/j.scitotenv.2015.02.005
Tiessen, H., E. Cuevas, and P. Chacon. 1994. The role of soil organic matter in sustaining soil fertility. Nature 371:783-785. https://doi.org/10.1038/371783a0

U.S. Department of Agriculture (USDA). 2015a. Basic report 11134, cassava, raw. Release 27. USDA Nutrient Data Laboratory, Beltsville, Maryland, USA.

U.S. Department of Agriculture (USDA). 2015b. Basic report 15010, fish, catfish, channel, wild, raw. Release 27. USDA Nutrient Data Laboratory, Beltsville, Maryland, USA.

U.S. Department of Agriculture (USDA). 2015c. Full report ( All nutrients) 09277, plantains, raw. Release 27. USDA Nutrient Data Laboratory, Beltsville, Maryland, USA.

U.S. Department of Agriculture (USDA). 2015d. Basic report 16069, lentils, raw. Release 27. USDA Nutrient Data Laboratory, Beltsville, Maryland, USA.

U.S. Department of Agriculture (USDA). 2015e. Basic report 20450, rice, white, medium-grain, raw, unenriched. Release 27. USDA Nutrient Data Laboratory, Beltsville, Maryland, USA.

U.S. Department of Agriculture (USDA). 2015f. Basic report 01123, egg, whole, raw, fresh. Release 27. USDA Nutrient Data Laboratory, Beltsville, Maryland, USA.

U.S. Department of Agriculture(USDA). 2019. Game meat, boar, wild, raw (SR legacy, 175297). FoodData Central, Agricultural Research Service, Washington, D.C., USA.

Vallejo, J. A., P. Miranda, J. D. Flores-Félix, F. Sánchez-Juanes, J. M. Ageitos, J. M. González-Buitrago, E. Velázquez, and T. G. Villa. 2013. Atypical yeasts identified as saccharomyces cerevisiae by MALDI-TOF MS and gene sequencing are the main responsible of fermentation of chicha, a traditional beverage from Peru. Systematic and Applied Microbiology 36(8):560-564. https:// doi.org/10.1016/j.syapm.2013.09.002

Verheijen, F., S. Jeffery, and A. Bastos. 2010. Biochar application to soils: a critical scientific review of effects on soil properties, processes and functions. Technical report. Joint Research Centre, Institute for Environment and Sustainability, European Commission, Brussels, Belgium.

Vitousek, P. M., and R. L. Sanford, Jr. 1986. Nutrient cycling in moist tropical forest. Annual Review of Ecology and Systematics 17:137-167. https://doi.org/10.1146/annurev.es.17.110186.001033

Wiersum, K. F. 1984. Surface erosion under various tropical agroforestry systems. Pages 231-239 in C. L. O'Loughlin and A. J. Pearce, editors. Proceedings of a symposium on effects of forest land use on erosion and slope stability. Environment and Policy Institute, East-West Center, University of Hawai'i, USA.

World Health Organization (WHO). 2006. Guidelines for the safe use of wastewater, excreta and greywater - Volume 1. Policy and regulatory aspects. WHO, Geneva, Switzerland.

Zapata-Ríos, G. 2001. Linking spatial data with population viability analysis: reserve network design in the northeastern Ecuadorian Amazon. Thesis. College of Arts and Sciences, University of Ohio, Athens, Ohio, USA. 